\title{
Sports App: Digitalization of Sports Basic Movement
}

\author{
Galih Priyambada ${ }^{1, *}$, Aba Sandi Prayoga ${ }^{2}$, Andy Widhiya Bayu Utomo², Deny Pradana Saputro ${ }^{3}$, \\ Rudi Hartono ${ }^{4}$ \\ ${ }^{1}$ Sports Education Study Program, Faculty of Teacher Training in Education, \\ Universitas Muhammadiyah Kalimantan Timur, Indonesia \\ ${ }^{2}$ Physical Education Health and Recreation, Sekolah Tinggi Keguruan dan Ilmu Pendidikan Modern Ngawi, Indonesia \\ ${ }^{3}$ Physical Education Health and Recreation, Faculty of Teacher Training in Education, Universitas Riau, Indonesia \\ ${ }^{4}$ Faculty of Education Technology, Universitas Ibn Khaldun Bogor, Indonesia
}

Received November 15, 2021; Revised January 7, 2022; Accepted February 8, 2022

\section{Cite This Paper in the following Citation Styles}

(a): [1] Galih Priyambada, Aba Sandi Prayoga, Andy Widhiya Bayu Utomo, Deny Pradana Saputro, Rudi Hartono , "Sports App: Digitalization of Sports Basic Movement," International Journal of Human Movement and Sports Sciences, Vol. 10, No. 1, pp. 85 - 89, 2022. DOI: 10.13189/saj.2022.100112.

(b): Galih Priyambada, Aba Sandi Prayoga, Andy Widhiya Bayu Utomo, Deny Pradana Saputro, Rudi Hartono (2022). Sports App: Digitalization of Sports Basic Movement. International Journal of Human Movement and Sports Sciences, 10(1), 85 - 89. DOI: 10.13189/saj.2022.100112.

Copyright $@ 2022$ by authors, all rights reserved. Authors agree that this article remains permanently open access under the terms of the Creative Commons Attribution License 4.0 International License

\begin{abstract}
Sport is an activity that requires various aspects of support, with the habit that is often done. This study aims to produce a processing system for basic sports results or basic motor skills using a digital-based application for basic movement skills in sports. The research method used in this case is a research and development approach or method. The data collection method used in this study is a questionnaire given to respondents to obtain accurate data. While the data analysis used qualitative and quantitative data analysis to obtain valid and effective value data. The results in this study indicate that the data processing application system to determine the basic skills or basic abilities that were developed received a positive assessment from the trainer with very good and sufficient criteria. The average rating of very good is $37.5 \%$, good is $50 \%$ and sufficient is as much as $12.5 \%$. Furthermore, description by respondents shows that the data processing application system for the results of basic abilities or basic abilities is declared valid and can be used without revision and with revision. Based on the results of this study, it can be said that the developed system is valid and can be used to process basic motor skills possessed by athletes or students.
\end{abstract}

Keywords Basic Movement, Digitalization, Software

\section{Introduction}

Achievement in sport is the goal of training, sport in the world of education is very closely related. Physical activity is an effort to achieve something. Physical movement ability in sports is something that must be given special attention or needs to be given a training to achieve optimal mobility results. In activities with motion activities in sports, it is necessary to get several supporting aspects. Among them is the periodization of exercise that can support the physical component. This is because a strong physical foundation has a great opportunity for the development of technical, tactical and mental aspects [1].

Recent advances in information technology have allowed athletes to improve performance during training and competition. Training is a systematic process to improve the athlete's ability to the maximum level [2], [3]. Some examples of development involving information technology in order to support sports achievements especially to support the development of physical aspects can be seen in some research products for the development of physical test processing management system development. Various forms of software have been created to manage the results of physical tests of sports.

The progress of the world's technological system today has shown its consistency, where many roles are collaborated with various fields, including in sports and education. Digital-based information technology systems 
are able to bring more optimal results and of course their existence can be accounted for and the contributions made tend to be clearer and can be felt by various parties, especially in the field of sports that can carry out the role of digital-based information technology that can support or increase optimization, function rather than exercise to environmental conditions or sports around.

Increasing the competence of sports in general is the most basic principle to be underlined as a consideration in trying to create a new solution. The solution that is expected in this case is always fundamental and can be applied to various fields in sports. Of course the application of this leads to the basic motion system such as throwing, jumping and so on. In other words, analyzing a motion that falls into the category of locomotor motion. Giving updates in terms of measuring instruments or observations as an evaluation of a movement should be a concern that cannot be abandoned.

The development of a media or application to assist activities in recording and providing an assessment of the results of motion on a basic component is something that is really needed. A student who has other activities as an athlete may have been given a routine physical test. However, in this case all measuring instruments or assessment tools used do not have reliability that can be maintained in consistency, or in other cases not yet have reliable validity. Through the efforts in this research, it is hoped that it will provide a novelty that can provide an overview of the results of basic abilities that can be measured and classified as material for consideration and evaluation. Components of physical movement performed by someone at random will affect the physical demands. This condition must be anticipated through basic motion exercises and with the development of this application later it will be able to record the depth of movement ability of each student or athlete [4].

Jumping is an ability that almost everyone is able to do, but not everyone can know the results or the quality of the movement from the jumps made. The strength of an athlete can unite a condition that can be a positive feedback so that it can be used as an improvement to improve every movement made, if there is a difficulty or an error. This research departs from a training in the sport of pencak slat which requires special attention to accommodate the results of each physical component carried out, but in this case it is still limited to the abilities of students and athletes of pencak silat.

\section{Materials and Methods}

This research uses research and development or $\mathrm{R} \& \mathrm{D}$ methods developed by Borg and Gall [5]. Data collection in this study was carried out by observing the events that occurred and then being given a questionnaire to provide field data which was then analyzed, so that it could provide an overview or real results according to field conditions. The research steps used in this study reached 9 out of 10 stages in the research and development step according to Borg and Gall, namely for product revision [6]. The subjects used in the study were 6 people. The subjects used were students of the East Kalimantan Special School for International Athletes who are members of the pencak silat sport.

Collecting data using a questionnaire that is used to determine the practicality [7] and effectiveness of the sports application development model to measure the basic movement ability of jumping for students or athletes in a special school environment for international sportsmen.

The data analysis techniques used in this research are qualitative data analysis techniques and quantitative data analysis techniques. The use of data analysis techniques qualitatively to discount the results of product assessments on small-scale tests and large-scale tests, while quantitatively used to see the percentage of assessments conducted by respondents.

\section{Result}

This research is a follow-up study conducted by the author by analyzing several existing studies. The research that became the interest and became the basis for the author to conduct this research, the research is: a survey of the physical abilities of students in an international sports special school. The purpose of this research is to provide an overview of the physical abilities of the sample or research subject, which will then be taken to a further realm, namely the formation or development of applications to support these basic actions.

Based on the results of the questionnaire about the system model that the author gave to 6 respondents in Point 1, namely: 2 respondents with a percentage of $33 \%$ considered very good, 4 respondents with a percentage of $67 \%$ good, 2 other respondents with a percentage of 33\% considered sufficient. Furthermore, in point 2 regarding system design, 1 respondent with a percentage of $16.7 \%$ is considered very good, 4 respondents with a percentage of $66.7 \%$ is considered good. 1 respondent with a percentage of $16.7 \%$ is considered sufficient. Furthermore, for point 3 ease of use, 2 respondents rated it very easy with a proportion of $33 \%$, while 4 or $66.7 \%$ respondents rated it easy. Then 0 respondents or $0 \%$ is considered sufficient. For point 4 regarding the selection of icons in the application, 1 respondent rated it very easy with a percentage of $16.7 \%, 4$ respondents rated it with a percentage of $66.7 \%$ and 1 respondent rated it quite enough with a percentage of $16.7 \%$. 


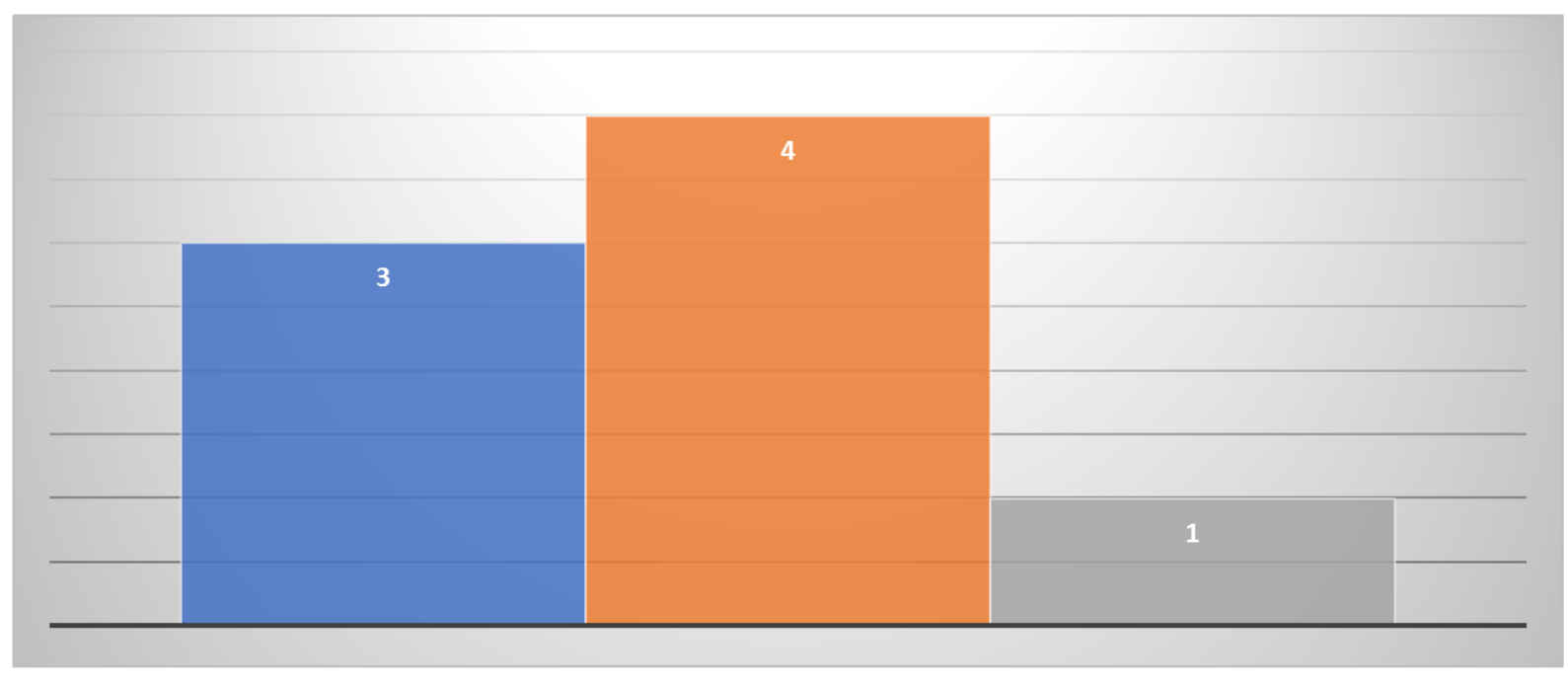

Figure 1. Respondent's Assessment

Furthermore, in point 5 regarding the application of the main spatial layout, 1 respondent rated it very easy with a percentage of $16.7 \%$, while 4 respondents or $66.7 \%$ rated it easy. 1 respondent or $16.7 \%$ considered it quite easy. Furthermore, in point 6 about the accuracy of choosing a font design. As many as 1 person with a percentage of $16.7 \%$ rated it very good, 4 other people rated $66.7 \%$ good, 1 respondent or $16.7 \%$ considered it sufficient. Details of point 7 Regarding the selection of the image code in the software that is in accordance with its function, as many as 2 people with a percentage of $33 \%$ are considered very good, 3 respondents with a proportion of $50 \%$ are considered good and 1 respondent with a proportion of $16.7 \%$ is considered sufficient. On point 8 regarding the suitability of the software layout design, 1 respondent with a proportion of $16.7 \%$ considered it very good, while 3 respondents or the other $50 \%$ considered it good or $30 \%$ and 2 respondents or $33 \%$ considered sufficient.

More complete, namely for all of the items in the very good category 3 with a percentage of $37.5 \%$, good category 4 or $50 \%$ and sufficient 1 with a percentage of $12.5 \%$. Furthermore, based on the calculation results, it is further explained as a whole or the average of each item which is then combined and explained in the table below.

Table 1. Average Respondent's Assessment

\begin{tabular}{|c|c|}
\hline Average & Percentage \\
\hline 3 & 37.5 \\
\hline 4 & 50.0 \\
\hline 1 & 12.5 \\
\hline
\end{tabular}

Also described in the form of a histogram above (Figure 1).

This study also uses strict assessments and corrections from respondents to obtain a clearer picture and search results and can describe the expected conditions or actual conditions. The criteria given regarding the right aspects, it can be seen that the development of a measurement system for basic movement abilities in students' basic skills gets a very valid assessment, it can be used without revision 3 out of 6 respondents who assessed it or with a percentage of $50 \%$.

\section{Discussion}

Technology was created to make human work easier. Especially in sports, technology has many functions [8], [9], Haag [10] said that the existence of information technology will be able to support sports information activities such as the creation of hardware, software, networks, databases related to sports. In addition, physical activity is very important to consider in participating in sports training activities [11]. Various technologies are made in addition to simplifying the work, of course there are other things that must be considered, namely in terms of economics, efficiency of use and so forth. In a journal of sports education, recreation and dance. Innovation will provide the benefits of speed in work (time efficiency), being able to provide comfort and ease of use to complete daily work as well as in the context of sports.

Development of special applications to determine or measure the results of basic movement skills or basic motor skills of jumping for students or athletes. This research is an attempt to complete the previous research which according to the researcher's analysis is still lacking. Several previous studies in building a digitalization system were only limited to sports and instruments which were also limited in availability. Meanwhile, in this study, the system developed is useful for all sports. The application system developed received a positive appreciation from the sport and related elements to support the training process and achievement efforts.

This research is a research that collaborates two 
scientific fields, namely sports and information technology to get a multipurpose finding that can support sports performance which so far still uses manual impressions. In the world of sports, it is divided into several types, one of which is achievement sports that lead to the achievement of championship results. But on the other hand, basic movement skills also lead to application in physical education. Elements of reliable technology will certainly add to the attractiveness of students to participate in learning activities. Because many things happen where students sometimes lack the appetite to participate in sports activities, especially female students who are the main reason for not participating in physical education learning activities [12]. The information system used in the world of sports is a special effort to get a real picture to prevent the possibility of errors made by humans manually, both technical elements and psychological elements that lead to a sense of concern and win some parties.

The results of this study indicate that the assessment of the Very system makes a positive contribution to efforts to record results or assess the results of measuring basic movement abilities. These results indicate that the system gets a positive assessment from the respondents. In addition, when viewed from a descriptive assessment, this system is very valid, it can be used without revision. Although some of the other respondents considered it quite valid, it can still be used even with revisions. However, if you look further, there is not a single statement from the trainer stating that this system cannot be used. The results of this study indicate that all respondents stated that this system can be used.

This can be further proven from the assessment of the main features in the system that get a good response from respondents or informants in the field of sports. If we pay closer attention, the resulting system in this case can also be used as a system to attract athletes or prospective students who will attend special schools for international sportsmen or children who are talented in terms of their physical aspects.

This research is a research that involves other sciences, namely information technology to solve existing problems. The system is intended to make it easier for users to process test results for basic movement skills using only one system, namely the sports test management system. The system developed can be used portable to process the results of physical tests of all sports. Regarding the processing of basic movement test results, research [13] shows that trainers need to digitize software-based physical tests as the processing of test results. This research strongly supports the research conducted by the researcher. The results of this study also do not contradict the statement that the benefits derived from the procurement of technology are essentially created and used by humans to make life easier. This research is also reinforced by the statement [14] that the procurement of management software for basic movement skills test results is intended so that trainers can manage test results effectively and efficiently.

Technological developments are the main reason for efforts to develop in various fields, to keep up with various changes towards things that are modern and have a tendency to be simpler. The development of media or a support system for sports activities has actually been eagerly awaited by the sports community, in addition to supporting activities in an effort to achieve achievements, as well as to provide convenience in various aspects of sports. The sport in question has a variety of directions, can be used in performance sports preparation events and can also be applied in educational sports. Because in this study it leads to motor skills, namely the basic movement of jumping for students or athletes. Sport in the world of education that is packaged in physical education teaches that a student should have an interest in subjects to increase interest in learning. Increased awareness and interest in the subject increases the potential for learning [15].

The form of exercise in sports certainly leads to the goal of measuring a physical component, the role of the application system is present to facilitate the process. On the other hand, it can increase interest and motivation because the element of technology actually brings a positive impression. Design variations in sports can encourage interest to produce positive effects in performance [16]. The role of sport and its linkage with the element of digitalization is very clear, providing a positive color and relationship to the development of sports, both in achievement sports and educational sports, to support the main goals of sports and education. Previously, it was also important to give an accuracy test to improve the robustness of the database [17], [18]. In addition, to support the consistency of the system, it is also necessary to pay attention to several main things or components including materials and so on.

The hope is of course that the development of this system can be practically useful and theoretically can contribute to sports science through a combination of information technology and sports science. More specifically, this study wants to find out whether the sports physical test management system made is valid and can be used to process physical test results for all sports

The development of a strategy with a very supportive system will add a positive contribution to the development and achievement of sport in general, and increase student interest in sports education. This is in line with the results of the research put forward by Indra Kasih [19]. The development of volleyball talent based on Android can be used to identify the strength of the sport of volleyball. Based on this description, it can be explained that the measurement media packaged using a simpler system can bring an optimal impact. The development of a multipurpose application system model is an effort to improve sports performance and make it easier for coaches and teachers to teach/train. 


\section{Conclusions}

Results Based on the research and discussion, it can be said that the locomotor basic motion management system specifically. Jumping movements are declared valid and can be used on a limited scale. The implication of procuring a digitalization system for processing the test results of basic jumping motion skills for students who are at the same time as athletes can be used to process the results of basic movement tests. This research provides an update on the digital application-based sports test method that can be used easily and access is not difficult. So that what distinguishes it from previous research is in the part of the test instrument which was originally in the form of developing a test instrument manually, in this case it is packaged in the form of digitization.

\section{REFERENCES}

[1] T. O. G. G. H. Bompa, Periodization: theory and methodology of training. 4th ed. Human Kinetics, Inc., 2009.

[2] D. G. Liebermann, L. Katz, M. D. Hughes, R. M. Bartlett, J. McClements, and I. M. Franks, "Advances in the application of information technology to sport performance," J. Sports Sci., vol. 20, no. 10, pp. 755-769, 2002, doi: $10.1080 / 026404102320675611$.

[3] N. C. Majid and Fauzi, "The effect of sprint training on vertical jump height of female youth volleyball players," Int. J. Hum. Mov. Sport. Sci., vol. 9, no. 2, pp. 334-339, 2021, doi: 10.13189/SAJ.2021.090222.

[4] B. Doyle, D. Browne, and D. Horan, "The relationship of aerobic endurance and linear speed on repeat sprint ability performance in female international footballers," Int. J. Hum. Mov. Sport. Sci., vol. 8, no. 4, pp. 147-153, 2020, doi: 10.13189/saj.2020.080407.

[5] M. Borg, W.R \& Gall, Educational Research. New York. Logham C.A., 2001.

[6] Sugiyono, Metode Penelitian Kuantitatif, Kualitatif dan R\&D. Bandung: Bandung: Alfabeta, 2016.

[7] P. Setyosari, "Book of Research and Development Model” Forth Edition,” Forth Edit., Jakarta. Published Prenadamedia Group, 2013.

[8] S. Loland, “Technology in Sport: Three Ideal-Typical Views and Their Implications," in The Ethics of Sports
Technologies and Human Enhancement, Routledge, 2020, pp. 163-172.

[9] S. Loland, "Technology in sport: Three ideal-typical views and their implications," Eur. J. Sport Sci., vol. 2, no. 1, pp. 1-11, 2002, doi: 10.1080/17461390200072105.

[10] H. Haag, "Sport science studies: Theoretical foundation of sport science as a scientific discipline. Schorndorf: Verlag Karl Hofmann.,” 1994, Accessed: Nov. 23, 2021. [Online]. Available: https://philpapers.org/rec/HAATFO-2.

[11] A. Ginanjar, M. Z. Mubarok, and D. O. Mudzakir, "College students' motivation after teaching using sport education season,” Int. J. Hum. Mov. Sport. Sci., vol. 9, no. 4, pp. 17, 2021, doi: 10.13189/saj.2021.091301.

[12] G. Griban et al., "Female Students' Motor Skills Development by Means of Kangoo Jumps,” Int. J. Hum. Mov. Sport. Sci., vol. 9, no. 6, pp. 1324-1343, 2021, doi: 10.13189/saj.2021.090629.

[13] D. Nurhidayah and M. Siswantoyo, "Need Assesment of Software Preparation for Pencak Silat Physical Test in Early Age,” vol. 278, no. YISHPESS, pp. 627-629, 2019, doi: 10.2991/yishpess-cois-18.2018.160.

[14] D. P. Saputro, M. R. A. Wijaya, and M. F. Dongoran, "Analisis Kebutuhan Software Pengelola Hasil Tes Fisik Pencak Silat Remaja Kategori Tanding,” JUARA J. Olahraga, vol. 5, no. 2, 2020, doi: 10.33222/juara.v5i2.920.

[15] S. P. Cumming, R. S. Lloyd, J. L. Oliver, J. C. Eisenmann, and R. M. Malina, "Bio-banding in Sport: Applications to Competition, Talent Identification, and Strength and Conditioning of Youth Athletes Sean,” vol. 39, no. 2, pp. 34-47, 2017, doi: https://doi: 10.1519/SSC.000000000000 0281.

[16] T. D’Isanto, F. Di Domenico, F. D’Elia, S. Aliberti, and G. Esposito, "The Effectiveness of Constraints-Led Training on Skill Development in Football,” Int. J. Hum. Mov. Sport. Sci., vol. 9, no. 6, pp. 1344-1351, 2021, doi: 10.13189/saj.2021.090630.

[17] E. van der Kruk and M. M. Reijne, "Accuracy of human motion capture systems for sport applications; state-of-the-art review," https://doi.org/10.1080/17461391. 2018.1463397, vol. 18, no. 6, pp. 806-819, Jul. 2018, doi: 10.1080/17461391.2018.1463397.

[18] G. Aroganam, N. Manivannan, and D. Harrison, "Review on Wearable Technology Sensors Used in Consumer Sport Applications," Sensors, vol. 19, pp. 1-26, 2019, doi: https://doi.org/10.3390/s19091983.

[19] I. Kasih, B. Hasibuan, and G. Priyambada, "Development of Polarization of Data Processing Talent Scouting Test of Android-Based Volleyball Sports,” vol. 32, no. 3, pp. 2300-2303, 2020, [Online]. Available: www.turkjphysiotherrehabil.org. 